\title{
Effects of Saline Drinking Water on Growth Performance and Mortality Rate of Japanese Quails (Coturnix coturnix Japonica)
}

\author{
Ghadir KHALILIPOUR ${ }^{1}$ (D), Naser MAHERI-SIS ${ }^{*}$ (i) , Abdolahad SHADDEL TELI ${ }^{3}$ (D), \\ Department of Animal Sciences, Shabestar Branch, Islamic Azad University, Shabestar, Iran. \\ ${ }^{1}$ https://orcid.org/0000-0001-5920-0574, ${ }^{2}$ https://orcid.org/0000-0001-6261-3273, ${ }^{3}$ https://orcid.org/0000-0002-3293-4639 \\ $\bowtie:$ nama1349@gmail.com
}

\begin{abstract}
This study was conducted to evaluate the effect of added different levels of common salt in drinking water on the production performance and mortality rate in Japanese quail chicks. A total of 600 one-day old ( $8.61 \pm 0.21$ grams) Japanese quail chicks divided into six treatment groups and five replicates of 20 birds per experimental units, based on completely randomized design for 42 days. All groups were fed the same diets and only amount of salt in the water differed. Control group consumed conventional drinking water and other treatments have $1.32,2.80,3.80,5.56$ and 7.12 grams of salt per liter which was equal to $233 \mathrm{ppm}$ total dissolved solids (TDS) for control group and 1233, 2233, 3233, 4233 and $5233 \mathrm{ppm}$ for other experimental groups, respectively. The results showed that feed intake (FI), body weight gain (BWG), live body weight (LBW) and feed conversion ratio (FCR) were significantly affected by water salinity $(p<0.0001)$. The highest FI and worst FCR were for treatment containing 5233 ppm TDS whereas the best FCR have been observed for treatments containing 233, 1233 and $2233 \mathrm{ppm}$ TDS. The mortality rate also significantly increased by the increasing TDS level in drinked water $(\mathrm{p}<0.0001)$. In conclusion, in order to maintain quail chicks performance at economic and acceptable range as well as least mortality, amount of TDS in drinking water should not be more than $2233 \mathrm{ppm}$.
\end{abstract}

\section{Research Article}

$\begin{array}{ll}\text { Article History } & \\ \text { Received } & : 13.04 .2019 \\ \text { Accepted } & : 23.05 .2019\end{array}$

Keywords

Common salt

Japanese quail

Mortality

Total dissolved solids

To Cite : Khalilipour G, Maheri Sis N, Shadddel Teli A 2019. Effects of Saline Drinking Water on Growth Performance and Mortality Rate of Japanese Quails (Coturnix coturnix Japonica). KSU J. Agric Nat, 22(6): 942-947. DOI: 10.18016/ksutarimdoga.vi.553366.

\section{INTRODUCTION}

Water quantity and quality are the significant challenges in arid to semi-arid regions of the world including Iran (Madani et al., 2016; VosooghiPostindoz et al., 2018). Average annual precipitation in Iran is lower than $250 \mathrm{~mm}$ which is $72 \%$ less than the global average of $814 \mathrm{~mm}$; so that the country is facing great water shortage, which resulted in drying lakes and rivers, reducing groundwater levels, increasing contamination and salinization of water, water supply rationing, salt and sand storms and increasing need to water desalination (Madani et al., 2016; Karandish and Hoekstra 2017). Drying Lake Urmia which is one of the world's largest hypersaline lakes, led to shortage, salinity and contamination of the water resources in north west of Iran (Karandish and Hoekstra 2017).

Water salinity is referred to the total concentration of soluble inorganic ions in particular sodium and chloride. Electrical conductivity (EC) and total dissolved solids (TDS) are usually used to measure water salinity (Atekwana et al., 2004; Rusydi 2018).
Yape Kii and Dryden (2005) cited that water salinity may cause harmful effects resulting in poor performance, illness or even death of animals. They have stated that adverse effects of salinity on health and performance varied based on species and breeds, adaptation and environment of animals. Alahgholi et al (2014), also stated that animal's tolerance to different amounts of $\mathrm{NaCl}$ in the water may depends on their species, age, water requirement, physiological condition, season of the year and salt content of total diet.

Nowadays, animal production industry is facing with both water scarcity and salinity in Iran. Thus, it seems that, there are no much more options for farmers other than efficient water utilisation, desalination of the water or using available water for adapted or resisted animals. Poultry producers in regions with high levels of water TDS, especially $\mathrm{NaCl}$ in water, try to solve the problem by reducing diet $\mathrm{NaCl}$ content and purifying saline water (Honarbakhsh et al., 2007).

Recently, Japanese quail (Coturnix coturnix Japonica) rearing have been increased in the country (Emami et 
al., 2015; Seifi et al., 2016; Saki et al., 2017) due to high yields in much more limited spaces, lower need to expensive investments and shorter production periods as well as higher income and qulity of products (Emami et al., 2012; Emami et al., 2015; Kalafova et al., 2018). Japanese quail is used as an animal model for different studies suitable for its eggs and meat production and it is more resistant to various diseases as well as environmental condition than that of chickens (Redoy et al., 2017; Kalafova et al., 2018). Althogh there is several researches in term of drinking saline water on health and production performance of meat and egg type poultries (Julian 1987; Barton 1996; Pourreza et al., 2000; Chen and Balnave 2001; Honarbakhsh et al., 2007; Kiani and Feizi 2008; Dai et al., 2009; Ahmed, 2013; Alahgholi et al., 2014; Elsaidy et al., 2015), but there is a little studies on the effect of water salinity on performance of Japanese quail (Shanawany et al., 1989; Erener et al., 2002).

This study was conducted to determine the effects of increasing TDS level of water by adding different levels of sodium chloride (common salt) to the water on production performance and mortality rate of Japanese quails.

\section{MATERIALS and METHODS}

\section{Experimental precedure}

A total of 600 one-day old unsexed Japanese quail chicks (8.61 \pm 0.21 grams) were obtained from commercial hatchery in East Azerbaijan, Iran, at winter of 2016 and divided into six groups comprising five replicates of 20 birds each, based on completely randomized design for 42 days. Ethical and animal care considerations approved by the Animal Research Committee in Islamic Azad University, Shabestar Branch (IAU-195), Shabestar, Iran. All treatments were reared at littered floor containing sawdust with 5 $\mathrm{cm}$ depth, in same conditions and fed the same diet (Table 1); formulated based on NRC (1994), only with different amounts of salt in their drinking water. Control treatment (T1) was consumed conventional drinking water (without adding any salt) and other treatments (T2- T6) have 1.32, 2.8, 3.8, 5.56 and 7.12 grams of salt per liter which was equal to $233 \mathrm{ppm}$ total dissolved solids (TDS) for control group (T1) and 1233, 2233, 3233, 4233 and $5233 \mathrm{ppm}$ for experimental groups (T2- T6), respectively. All birds have free access to drinking water based on treatments. Electrical conductivity (EC) of the treatments was measured by EC meter in the laboratoriy of chemistry, Islamic Azad University, Shabestar, Iran. Amounts of TDS were calculated using EC data by the equation: $\operatorname{TDS}=640$ * EC where; TDS as ppm and EC as dS/m (Atekwana et al., 2004).

\section{Statistical Analysis}

Experimental data were subjected to analysis of variance (ANOVA) as a completely randomized design (CRD) with six treatments and five replicates for each treatment, using general linear model (GLM) procedure of SAS (2008) and then, treatment means were compared by Duncan multiple range tests (Steel et al., 1997).

Table 1. Feed Ingredients and Nutrient Contents of Experimental Diets of Japanese Quails at Whole Growing Period (1-42d)

\begin{tabular}{ll}
\hline Feed ingredients & $(\%)$ \\
\hline Corn grain & 52.89 \\
Soy bean meal (44\% CP) & 38.80 \\
Corn gluten (60\% CP) & 3.93 \\
Sunflower oil & 1.32 \\
Oyster shell & 1.34 \\
Dicalcium phosphate & 0.77 \\
Common salt & 0.25 \\
Vitamins premix & 0.25 \\
Minerals premix & 0.25 \\
DL-Methionine & 0.12 \\
HCL- Lysine & 0.08 \\
\hline Nutrients (calculated) & \\
\hline Metabolisable energy (Kcal/kg) & 2900 \\
Crude protein (\%) & 24.00 \\
Crude fiber (\%) & 3.93 \\
Ca (\%) & 0.80 \\
P available (\%) & 0.29 \\
Methionine (\%) & 0.50 \\
Methionine+ Cysteine & 0.93 \\
Lysine (\%) & 1.30 \\
Na (\%) & 0.11 \\
Cl (\%) & 0.19 \\
\hline
\end{tabular}

\section{RESULTS and DISCUSSION}

\section{Effect of water salinity on feed intake (FI)}

Effect of water salinity on FI of Japanese quails at 121 days, 21-42 days and whole experimental period (142 days of age) illustrated in Tables 2-4. There are significant differences between experimental treatments at the rearing periods of $1-21(\mathrm{p}<0.0001)$, $21-42(\mathrm{p}<0.0001)$ and $1-42$ days of age $(\mathrm{p}<0.0001)$. At the 1-21 days of age (Table 2); T1, T2, T3 and T4 (treatments containing 233, 1233, 2233 and $3233 \mathrm{ppm}$ TDS in water) had significantly lower FI than T5 and T6 (treatments containing 4233 and 5233 ppm TDS in water, respectively). At the period of 21-42 days of age (Table 3) as well as whole period of the experiment (Table 4), T6 had higher and T3 had lower FI than other groups. Our results are similar to the findings of Sklan and Noy (2000) as well as Honarbakhsh et al (2007). They indicated that using high levels of sodium increased FI due to stimulating role of this element on appetite as well as absorption. They have suggested that sodium has a very important role on FI just after hatching and also in secretion and activity of some digestive enzymes. Olanrewaju et al (2007) also supposed that FI may be increased by increasing $\mathrm{Na}$ 
level in poultry diets due to physiological functions of sodium as an effective enzyme activator in the body. Jankowski et al (2011) supported that in fast-growing chickens an intake of dietary sodium higher than that of NRC (1994) recommendations, has a beneficial effect on feed consumption. In contrast of our study, Chen and Balnave (2001) concluded that higher inclusion of $\mathrm{NaCl}$ in drinking water could not affect FI in laying hens. Same results also reported by Mahmud et al (2010) in broiler chickens and Erener et al (2002) in Japanese quails. Besides, Alahgholi et al (2014) found no effects of water salinity on FI at any stages of broilers rearing period. However, they have cited that sensitivity or tolerance of animals to water salinity and its effects on their performance may be dependent on their species, age, and water requirement, and physiological condition, season of the year and salt content of total diet. Shanawany et al (1989) examined the effect of amounts of $0,500,1000$ and $1500 \mathrm{ppm}$ sodium chloride in the drinking water of Japanese quails and concluded that FI decreases as salt concentration increases. Also, Afifi et al (1992) reported that feed consumption of broiler chickens decreased as a result of high sodium chloride level in the drinking water. This may be related to loss of appetite owing to lesions of the appetite center in the lateral nucleus of the hypothalamus as well as inflammation in the rectum of birds caused decrease in FI drastically and this effect presumably was mediated via hypothalamus. Moreover, the crop of the birds has limited capacity. Saline water conduced to increased water consumption probably at the cost of feed consumption.

\section{Effect of water salinity on body weight gain (BWG) and} live body weight (LBW)

Effect of water salinity on BWG and LBW of Japanese quails at 1-21 days, 21-42 days and whole experimental period (1-42 days of age) indicated in Tables 2-4. There are significant differences between experimental treatments at the periods of $1-21$ $(p<0.0001), 21-42 \quad(p<0.0001)$ and $1-42$ days of age $(p<0.0001)$. At the 1-21 days of age (Table 2), the highest BWG and LBW obtained for control group (T1) and the lowest were observed in T3, T4, T5 and T6. At the period of 21-42 days of age (Table 3), BWG and LBW significantly affected by the TDS levels so that T3 had lowest BWG and LBW. At the whole period of experiment (Table 4), control group had the highest and T3 had the lowest BWG and LBW. Overall, TDS levels lower than $2233 \mathrm{ppm}$ conduce to better growth performance while higher levels leads to lower BWG and LBW. In line with our findings, Ahmed (2013) concluded that up to $2610 \mathrm{ppm}$ of TDS in drinking water had not negative effects on broiler growth performance, while higher levels resulted in adverse effects growth rate of experimental birds. The study suggests that a TDS level of 2610 ppm has a better effect on broiler performance, in terms of BWG as well as immunity in hot weather even compared with the control group. NRC (1994) suggested that, the water TDS of less than 1000 ppm should present no adverse effects on growth and production performance to any class of poultry, but higher levels may affect their health and performance. Kettunen et al (2001) demonstrated that consumption of water with higher salinity may exert negative effects on performance traits of the birds due to deterioration of osmotic pressure and intracellular metabolism. Goldstein \& Skadhauge (2000) declared that increasing TDS level in drinking water above $1500 \mathrm{ppm}$, led to enhance osmotic stress which in turn increases urination, and when rises above $3000 \mathrm{ppm}$, osmotic regulation is strike a balance. Barton (1996) reported that drinking water with TDS higher than 3000 ppm causes growth rate depression. Afifi et al (1992) suggested that depression of BW in saline water drinking birds is related to the increasing levels of glucocorticoids and correlated between adrenal size and body weight as well as severe diarrhea.

\section{Effect of water salinity on feed conversion ratio (FCR)}

Effect of water salinity on feed conversion ratio of Japanese quails at 1-21 days, 21-42 days and whole experimental period (1-42 days of age) demonstrated in Tables 2-4. There are significant differences between experimental treatments at the periods of 1-21 $(p<0.0001), 21-42 \quad(p<0.0001)$ and $1-42$ days of age $(p<0.0001)$. At the $1-21$ days of age (Table 2), feed conversion ratio adversely affected by increasing TDS level in drinking water. The best (lowest) feed conversion ratio observed in $\mathrm{T} 1$ and $\mathrm{T} 2$ and the worst (highest), were in T5 and T6. However at the period of 21-42 days of age (Table 3), the lowest FCR was for the T1 and T3, and highest was for T6. At whole experimental period (Table 4), also FCR adversely affected by increasing TDS level in drinking water and T1, T2 and T3 were the best and T6 was the worst treatment. It means that, at whole period of the experiment TDS levels higher than 2233 ppm resulted in higher FCR and consequently lower productivity. In agreement with our results, Honarbakhsh et al (2007) observed that enhancing salinity of drinking water can increases feed conversion ratio (FCR) and reduces performance of broiler chickens due to impaired cationanion balance which in turn it affects a lot of physiological and metabolic functions of body. Moreover, they have mentioned that young chicks are more susceptible to salt than older birds. However, Erener et al (2002) examined the performance of Japanese quails at 42 days of age offered sodium chloride provided through drinking water and did not observed significant differences between the treatment groups in terms of FI, BWG, LBW, FCR, water consumption or water to feed consumption ratio. 
Table 2. Effect of Water Salinity (TDS) Levels on Production Performance of Japanese Quails at 1-21 Days of Age

\begin{tabular}{lllll}
\hline Treatments & FI $(\mathrm{g})$ & BWG $(\mathrm{g})$ & LBW $(\mathrm{g})$ & FCR $(\mathrm{g} / \mathrm{g})$ \\
\hline T1 & $302.23 \mathrm{~b}$ & $124.3 \mathrm{a}$ & $133.30 \mathrm{a}$ & $2.42 \mathrm{a}$ \\
T2 & $295.63 \mathrm{~b}$ & $118.9 \mathrm{~b}$ & $127.87 \mathrm{~b}$ & $2.48 \mathrm{a}$ \\
T3 & $285.45 \mathrm{~b}$ & $101.8 \mathrm{c}$ & $111.34 \mathrm{c}$ & $2.80 \mathrm{~b}$ \\
T4 & $286.38 \mathrm{~b}$ & $104.3 \mathrm{c}$ & $113.25 \mathrm{c}$ & $2.74 \mathrm{~b}$ \\
T5 & $320.65 \mathrm{a}$ & $102.4 \mathrm{c}$ & $111.35 \mathrm{c}$ & $3.12 \mathrm{c}$ \\
T6 & $335.40 \mathrm{a}$ & $102.5 \mathrm{c}$ & $111.47 \mathrm{c}$ & $3.27 \mathrm{c}$ \\
P value & $<0.0001$ & $<0.0030$ & $<0.0001$ & $<0.0001$ \\
SEM & 5.778 & 0.6025 & 0.6542 & 0.0566 \\
\hline
\end{tabular}

Means in the same column with different letters ( $a, b$ and c) are differ $(\mathrm{P}<0.05)$.

T1- T6 containing 233, 1233, 2233, 3233, 4233 and 5233 ppm total dissolved solids (TDS), respectively.

SEM: standard error of means

Table 3. Effect of Water Salinity (TDS) Levels on Production Performance of Japanese Quails at 21-42 Days of Age

\begin{tabular}{lllll}
\hline Treatments & FI $(\mathrm{g})$ & BWG $(\mathrm{g})$ & LBW $(\mathrm{g})$ & FCR $(\mathrm{g} / \mathrm{g})$ \\
\hline T1 & $378.12 \mathrm{~b}$ & $104.95 \mathrm{ab}$ & $238.25 \mathrm{a}$ & $3.56 \mathrm{a}$ \\
T2 & $404.07 \mathrm{~b}$ & $105.12 \mathrm{ab}$ & $232.50 \mathrm{~b}$ & $3.83 \mathrm{~b}$ \\
T3 & $327.57 \mathrm{c}$ & $97.66 \mathrm{c}$ & $209.25 \mathrm{e}$ & $3.59 \mathrm{a}$ \\
T4 & $386.01 \mathrm{~b}$ & $104.25 \mathrm{ab}$ & $217.50 \mathrm{~cd}$ & $3.70 \mathrm{bc}$ \\
T5 & $397.05 \mathrm{~b}$ & $108.14 \mathrm{a}$ & $219.50 \mathrm{c}$ & $3.65 \mathrm{bc}$ \\
T6 & $427.49 \mathrm{a}$ & $102.77 \mathrm{~b}$ & $214.25 \mathrm{~d}$ & $4.15 \mathrm{c}$ \\
P value & $<0.0001$ & $<0.0030$ & $<0.0001$ & $<0.0001$ \\
SEM & 9.42 & 1.42 & 1.33 & .066 \\
\hline
\end{tabular}

Means in the same column with different letters (a-d) are differ $(\mathrm{P}<0.05)$.

T1- T6 containing 233, 1233, 2233, 3233, 4233 and 5233 ppm total dissolved solids (TDS), respectively.

SEM: standard error of means

Table 4. Effect of Water Salinity (TDS) Levels on Production Performance of Japanese Quails at 1-42 Days of Age

\begin{tabular}{llllll}
\hline Treatments & FI $(\mathrm{g})$ & BWG $(\mathrm{g})$ & LBW $(\mathrm{g})$ & FCR $(\mathrm{g} / \mathrm{g})$ & Mortality Rate $(\%)$ \\
\hline T1 & $680.33 \mathrm{bc}$ & $229.00 \mathrm{a}$ & $238.25 \mathrm{a}$ & $2.97 \mathrm{a}$ & $06.01 \mathrm{a}$ \\
T2 & $699.70 \mathrm{bc}$ & $224.00 \mathrm{~b}$ & $232.50 \mathrm{~b}$ & $3.13 \mathrm{a}$ & $12.11 \mathrm{~b}$ \\
T3 & $634.18 \mathrm{~d}$ & $200.25 \mathrm{e}$ & $209.25 \mathrm{e}$ & $3.16 \mathrm{a}$ & $16.06 \mathrm{bc}$ \\
T4 & $669.87 \mathrm{~cd}$ & $208.50 \mathrm{~cd}$ & $217.50 \mathrm{~cd}$ & $3.22 \mathrm{bc}$ & $21.04 \mathrm{c}$ \\
T5 & $717.95 \mathrm{~b}$ & $210.50 \mathrm{c}$ & $219.50 \mathrm{c}$ & $3.40 \mathrm{~b}$ & $31.09 \mathrm{~d}$ \\
T6 & $762.90 \mathrm{a}$ & $205.25 \mathrm{~d}$ & $214.25 \mathrm{~d}$ & $3.71 \mathrm{c}$ & $49.00 \mathrm{e}$ \\
P value & $<0.0001$ & $<0.0001$ & $<0.0001$ & $<0.0001$ & $<0.0001$ \\
SEM & 12.42 & 1.26 & 1.30 & 0.06 & 1.715 \\
\hline
\end{tabular}

Means in the same column with different letters (a-e) are differ $(\mathrm{P}<0.05)$.

T1- T6 containing 233, 1233, 2233, 3233, 4233 and 5233 ppm total dissolved solids (TDS), respectively

SEM: standard error of mean

Also, in contrast with our findings, Dai et al (2009) reported that addition of $0.4 \%$ comparing $0.2 \% \mathrm{NaCl}$ in drinking water, increased BWG and improved FCR. Afifi et al (1992) declared that higher FCR in birds that offered drinking water with higher salinity may be due to severe diarrhea and subsequent weight loss of birds.

\section{Effect of water salinity on mortality rate}

Effect of water salinity on mortality rate of Japanese quails in the whole experimental period (1-42 days of age) showed in Tables 4 . Mortality of the quails was significantly $(p<0.0001)$ affected by the increasing TDS level in drinking water; which was varied between $6 \%$ for $\mathrm{T} 1$ to $49 \%$ for T6. Mortality rate have increased by increasing drinking water salinity. Increasing mortality of birds by increasing TDS levels in drinking water has been reported by several researchers (Julian 1987; Ali Maie et al., 1992; Barton 1996; Pourreza et al., 2000; Erener et al., 2002; Honarbakhsh et al., 2007; Kiani and Feizi, 2008). Julian (1987) had been stated that excess sodium chloride in the diet and drinking water cause ascites and oedema in poultry. Sodium is the toxic ion in salt poisoning and young poultry may be at particular risk from excess sodium because they have lower plasma osmolarity and undeveloped kidneys. Ali Maie et al (1992) showed that salt stress caused substantial increase in respiratory rate, 
hematocrit values and total plasma protein levels of the broiler chicks which in turn leads to increasing mortality. They have concluded that in broiler chicks the tolerable level of salt in drinking water is $2 \mathrm{~g} / \mathrm{L}$. Barton (1996) concluded that drinking water with TDS in excess of $3000 \mathrm{ppm}$ resulted in increased flock mortality. Pourreza et al (2000) indicated that using water with higher levels of TDS had the most negative effects on mortality rate in the rearing period of broilers and up to $56.2 \%$ mortality was recorded at the highest TDS content (more than $5000 \mathrm{ppm}$ ). They have concluded that gastro intestinal, liver and kidney lesions as well as acid-base imbalance and coccidiosis due to salt stress may be the main reasons of mortality. Also in the experiment of Erener et al (2002) mortality rate of Japanese quails in particulate newly hatched chicks was increased by enhancing $\mathrm{NaCl}$ level of the drinking water. Honarbakhsh et al (2007) found the adverse effects of higher TDS on mortality, particularly in young chicks which are more susceptible to salt than older birds. A number of mortalities in their study caused by ascites which caused by salt overdose and osmotic difference between plasma and tissue. They have cited that high levels of sodium chloride in drinking water leads to increase blood pressure, heart failure, water consumption and litter moisture and therefore resulted in increasing occurrence of some diseases such as ascites and coccidiosis and consequently increasing mortality rate. Kiani and Feizi (2008) characterized that using drinking water with higher than $350 \mathrm{ppm}$ sodium concentration resulted in higher mortality rate. Watkins et al (2005) suggested that dietary levels of sodium and chloride should adjusted based on levels of these elements in the drinking water. Moreover, they have estimated that sodium in the drinking water may replace even complete supplemental sodium in the diet.

\section{CONCLUSION}

Based on the results of current study, it can be concuded that, in order to maintaining quail chicks performance at economic and acceptable range as well as least mortality, amout of TDS in drinking water should not be more than $2233 \mathrm{ppm}$. So, higher salinity in drinking water leads to higher FI, FCR and mortality rate and lower body weight gain and finally lower profitability.

\section{ACKNOWLEDGMENTS}

This article adopted from M.Sc. thesis in animal science, Shabestar Branch, Islamic Azad University (thesis supervisor: Dr. N. Maheri-Sis). The authors are grateful to the Animal Research Center and laboratories of Shabestar Branch, Islamic Azad University, Shabestar, Iran.

\section{CONFLICT of INTEREST}

The authors declare that there is no conflict of interest regarding the publication of this article.

\section{REFERENCES}

Afifi M, Maie FA, Abdel-Maksoud AM 1992. Salt stress in broiler chicks: 1 . Report: effect of salt stress on some productive traits in broiler chicks. Archiv fur Geflugelkunde 56: 124-128.

Ahmed AS 2013. Performance and immune response of broiler chicks as affected by different levels of total dissolved solids in drinking water under hot arid environments. Animal Production Science, 53: 322327.

Alahgholi M, Tabeidian SA, Toghyani M, Ale Saheb Fosoul SS 2014. Effect of betaine as an osmolyte on broiler chickens exposed to different levels of water salinity. Archiv fur Tierzucht, 57:1-12.

Ali Maie F, Mekkawy MY, Afifi M, A M Abdel-Maksoud 1992. Salt stress in broiler chicks: II. Effect of sodium chloride stress on plasma hormonal levels and other blood constituents in broiler chicks. Archiv fur Geflugelkunde 56: 241-246.

Atekwana EA, Atekwana EA, Rowe RS, Dale Werkema JR, Franklyn DL 2004. The relationship of total dissolved solids measurements to bulk electrical conductivity in an aquifer contaminated with hydrocarbon. Journal of Applied Geophysics, 56: 281-294.

Barton TL 1996. Relevance of water quality to broiler and turkey performance. Poultry Science, 75: 854856.

Chen J, Balnave D 2001. The influence of drinking water containing sodium chloride on performance and eggshell quality of a modern, colored layer strain. Poultry Science, 80:91-94.

Dai NV, Bessei W, Quang NH 2009. The effects of sodium chloride and potassium chloride supplementation in drinking water on performance of broilers under tropical summer conditions. Archiv fur Geflugelkunde 73: 41-48.

Emami F, Maheri-Sis N, Ghorbani A, Vahdatpour T 2012. Effects of feeding untreated or reconstituted sorghum grain (Sorghum bicolor L.) on growth performance of Japanese quails (Coturnix coturnix japonica). International Journal of Biosciences, 2: 31-37.

Emami F, Maheri-Sis N 2015. Effects of reconstitution of high tannin sorghum grain on small intestine morphometry of Japanese quails. Trakia Journal of Sciences, 13: 77-82.

Elsaidy N, Mohamed RA, Abouelenien F 2015. Assessment of variable drinking water sources used in Egypt on broiler health and welfare. Veterinary World, 8: 855-864.

Erener G, Ocak N, Ozdas A 2002, Effect of sodium chloride supplementation provided through 
drinking water and/or feed on performance of Japanese quails (Coturnix coturnix Japonica). Turkish Journal of Veterinary and Animal Sciences, 26: 1081-1085.

Goldstein DL, Skadhauge E 2000. Renal and Extrarenal Regulation of Body Fluid Composition. In: Whittow GC (ed.) Sturkie's Avian Physiology. $5^{\text {th }}$ edition, Academic Press, San Diego, USA, pp. 265297.

Honarbakhsh S, Zaghari M, Shivazad M 2007. Interactive effects of dietary betaine and saline water on carcass traits of broiler chicks. Journal of Biological Sciences, 7: 1208-1214.

Jankowski J, Zduñczyk Z, Juoekiewicz J, Kwieciñski P 2011. Effect of different dietary sodium levels on the growth performance of broiler chickens, gastrointestinal function, excreta moisture and tibia mineralization. Journal of Animal and Feed Sciences, 20: 93-106.

Julian RJ 1987. The effect of increased sodium in the drinking water on right ventricular hypertrophy, right ventricular failure, ascites in broiler chickens. Avian Pathology, 16: 61-71.

Kalafova A, Hrncar C, Zbynovska K, Bucko O, Hanusova E, Kapustova Z, Schneidgenova M, Bielik P, Capcarova M 2018. The effects of dietary probiotics and humic acid on meat quality of Japanese quail including sex-related differences and economical background. Biologia, 73: 765-771.

Karandish F, Hoekstra AY 2017. Informing national food and water security policy through water footprint assessment: the case of Iran. Water 9: 125.

Kettunen H, Peuranen S, Tiihonen K 2001. Betaine aids in the osmoregulation of duodenal epithelium of broiler chicks, and affects the movement of water across the small intestinal epithelium in vitro. Comparative Biochemistry and Physiology Part A: Molecular \& Integrative Physiology, 129: 595-603.

Kiani R, Feizi A 2008. The study of relation between normal and higher than standard concentration of sodium of drinking water in ascites syndrome declaration in broiler chickens. International Journal of Poultry Science, 7: 89-91.

Madani K, AghaKouchak A, Mirchi A 2016. Iran's socio-economic drought: challenges of a waterbankrupt nation. Iranian Studies-UK, 49: 9971016.

Mahmud A, Hayat Z, Zafarullah Khan M, Khalique A, Younus M 2010. Comparison of source and levels of sodium in broilers under low temperature conditions. Pakistan Journal of Zoology, 42: 383388.

NRC 1994. Nutrient Requirements of Poultry. 9th edition. The National Academies Press, Washington, DC.

Olanrewaju HA, Thaxton JP, Dozier WA, Branton SL 2007. Electrolyte diets, stress, and acid-base balance in broiler chickens. Poultry Science, 86: 1363-1371.

Pourreza J, Nasrollahi H, Samie AH, Mohammadalipour M, Assadian A 2000. The effects of total dissolved solids (TDS) on performance of broiler chickens. Journal of Science and Technology of Agriculture and Natural Resources, 3:71-82.

Redoy MRA, Shuvo AAS, Al-Mamun M 2017. A review on present status, problems and prospects of quail farming in Bangladesh. Bangladesh Journal Animal Science, 46: 109-120.

Rusydi AF 2018. Correlation between conductivity and total dissolved solid in various type of water: A review. IOP Conference Series: Earth and Environmental Science, 118: 1-6.

Saki AA, Mirzaie Goudarzi S, Ranjbaran M, Ahmadi A, Khoramabadi V 2017. Evaluation of biochemical parameters and productive performance of Japanese quail in response to the replacement of soybean meal with canola meal. Acta Scientiarum Anim Sciences, 39: 51-56.

SAS 2008. User's Guide. SAS Institute Inc., Cary, NC, USA

Seifi K, Karimi Torshizi MA, Abbasi S, Kazemifard M 2016. Effects of microwave-treated drinking water on growth and some physiological characteristics of Japanese quail (Coturnix coturnix Japonica). Iranian Journal of Applied Animal Science, 6: 447451.

Shanawany MM, Abdel-Rahman KM, Akl MO 1989. Influence of sodium chloride concentration in drinking-water on shell quality of quail eggs. Proceeding of $3^{\text {rd }}$ European WPSA Symposium on Egg Quality, Stuttgart, Germany, 379-383.

Sklan D, Noy Y 2000. Hydrolysis and absorption in the small intestines of post hatch chicks. Poultry Science, 79: 1306-1310.

Steel RGD, Torrie JH, Dickey DA 1997. Principles and Procedures of Statistics. A Biometrical Approach, 3rd Ed. McGraw Hill Book Co., New York.

Vosooghi-Postindoz V., Tahmasbi A., Naserian A.A., Valizade R. and Ebrahimi H 2018. Effect of water deprivation and drinking saline water on performance, blood metabolites, nutrient digestibility, and rumen parameters in Baluchi lambs. Iranian Journal of Applied Animal Science, 8: $445-456$.

Watkins SE, Fritts CA, Yan F, Wilson ML, Waldroup PW 2005. The interaction of sodium chloride levels in poultry drinking water and the diet of broiler chickens. Journal of Applied Poultry Research, 14: $55-59$.

Yape Kii W, Dryden McL G 2005. Effect of drinking saline water on food and water intake, food digestibility, and nitrogen and mineral balances of rusa deer stags (Cervus timorensis russa). Animal Science, 81: 99-105. 